\title{
Scale and diversity of the physical technosphere: A geological perspective
}

The Anthropocene Review 20I7, Vol. 4(I) 9-22

(C) The Author(s) 2016

Reprints and permissions: sagepub.co.uk/journalsPermissions.nav DOI: $10.1177 / 2053019616677743$ journals.sagepub.com/home/anr

@SAGE

\author{
Jan Zalasiewicz,' Mark Williams,' Colin N Waters, ',2 \\ Anthony D Barnosky, ${ }^{3}$ John Palmesino, ${ }^{4}$ \\ Ann-Sofi Rönnskog, ${ }^{5}$ Matt Edgeworth, ${ }^{6}$ Cath Neal, ${ }^{7}$ \\ Alejandro Cearreta, ${ }^{8}$ Erle C Ellis, ${ }^{9}$ Jacques Grinevald, ${ }^{10}$ \\ Peter Haff, " Juliana A Ivar do Sul, ${ }^{2}$ Catherine Jeandel, 13 \\ Reinhold Leinfelder, ${ }^{14}$ John R McNeill, ${ }^{15}$ Eric Odada, ${ }^{16}$ \\ Naomi Oreskes, ${ }^{17}$ Simon James Price, ${ }^{2,18}$ Andrew Revkin, ${ }^{19}$ \\ Will Steffen, ${ }^{20}$ Colin Summerhayes, ${ }^{21}$ Davor Vidas, ${ }^{22}$ \\ Scott Wing ${ }^{23}$ and Alexander P Wolfe ${ }^{24}$
}

\begin{abstract}
We assess the scale and extent of the physical technosphere, defined here as the summed material output of the contemporary human enterprise. It includes active urban, agricultural and marine components, used to sustain energy and material flow for current human life, and a growing residue layer, currently only in small part recycled back into the active component. Preliminary estimates suggest a technosphere mass of approximately 30 trillion tonnes $(\mathrm{Tt})$, which helps support a human biomass that, despite recent growth, is $\sim 5$ orders of magnitude smaller. The physical technosphere includes a large, rapidly growing diversity of complex objects that are potential trace fossils or 'technofossils'. If assessed on palaeontological criteria, technofossil

\footnotetext{
'Department of Geology, University of Leicester, UK ${ }^{2}$ British Geological Survey, UK

3 Jasper Ridge Biological Preserve, Stanford University, USA

${ }^{4}$ Architectural Association School of Architecture, UK ${ }^{5}$ Oslo Centre for Urban and Landscape Studies, Norway

${ }^{6}$ School of Archaeology and Ancient History, University of Leicester, UK

7University of York, UK

${ }^{8}$ Universidad del País Vasco, Spain

University of Maryland, USA

IOIHEID, Switzerland

${ }^{12}$ Federal University of Rio Grande, Brazil

${ }^{13}$ LEGOS (CNRS/CNES/IRD/Université Paul Sabatier),

France
}

"Duke University, USA

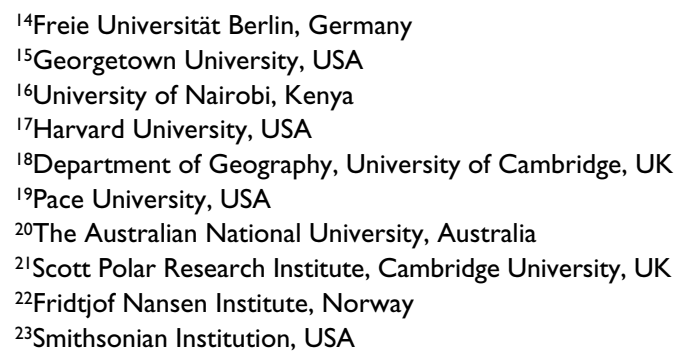


diversity already exceeds known estimates of biological diversity as measured by richness, far exceeds recognized fossil diversity, and may exceed total biological diversity through Earth's history. The rapid transformation of much of Earth's surface mass into the technosphere and its myriad components underscores the novelty of the current planetary transformation.

\section{Keywords}

Anthropocene, anthroposphere, artefacts, stratigraphy, technology, technosphere

\section{Context of the physical technosphere}

Organisms interact dynamically with the abiotic world around them and with each other, as they seek the resources they need to live and reproduce. Plants root themselves in the soil and absorb water and nutrients from it, take in carbon dioxide from the air and excrete oxygen back into it. Herbivorous animals eat the plants and excrete their undigested remains back on to the soil, while absorbing oxygen from the air and respiring carbon dioxide - and frequently emitting methane back into it. Carnivores eat the herbivores and likewise excrete their undigested remains on to the land surface, which are then reworked by consortia of microbes and invertebrates. Similar processes occur in the marine realm with the cycling of biomass between phytoplankton primary production, organisms that consume phytoplankton and carnivores that in turn consume them, with returns of organic matter to the water column and seabed occurring at each trophic level.

Some organisms may modify the habitable surface around them as shelter. Protozoans such as the aquatic agglutinated foraminifera build tests from sand and silt grains. Nest-builders include birds, ants and termites, while there are burrowing organisms both on land and under the sea. A few animals are tool-users: not only non-human primates (Koops et al., 2015), but birds (Roelofs, 2010), cetaceans (Krützen et al., 2005), fish, octopi, ants and wasps. Some of the largest mammalian herbivores and carnivores, and even small mammals such as beavers and prairie dogs, are ecosystem engineers (Wright et al., 2002).

However, Homo sapiens sapiens has, by far, gone the furthest in using technology - machines, factories, computers and such - to consciously or unwittingly alter the surrounding environment, to extract minerals, generate energy, make food and shelter, provide global communication, and so on. This modification is made possible by humanity's sophisticated social structure (Ellis, 2015), and by our species' 'object orientation' (Koops et al., 2015), which pre-disposes technology use. The interaction between people, societies and their technology has grown in importance through human history, becoming ever more sophisticated in a manner reminiscent of co-evolution (Basalla, 1988; Mesoudi et al., 2006). Today, human influence on materials extends globally, including deep underground and into outer space. As technology became more sophisticated, it opened new opportunities that humans and their societies exploited, which in turn prompted development of yet more varied and complex technology. Human-tool interactions hence seem critically important: these are now evolving (sensu lato) from generation to generation at rates that vastly outpace the modification, via natural selection, of not only our species, but of all known species.

One way to describe and analyse this modification is via the concept of the technosphere (here sensu Haff, 2014; see also Hall, 1975; Milsum, 1968), a new component of the Earth System that may be considered an offshoot of the biosphere sensu Vernadsky (1929). The technosphere as defined here comprises our complex social structures together with the physical infrastructure and technological artefacts supporting energy, information and material flows that enable the system to 
work, including entities as diverse as power stations, transmission lines, roads and buildings, farms, plastics, tools, airplanes, ballpoint pens and transistors. The components of the technosphere co-evolve rapidly, with complex and frequently changing lead-lag relationships predicated by additional constructs reserved to the human species, such as behaviours modulated by markets' supply and demand. The technosphere overlaps broadly, and interacts intimately, with the other spheres, an example being humans and their domestic animals and cultivated plants, which now make up much of the biosphere and are embedded within the technosphere, while humans are also the generators of the technosphere. This is analogous to water being an essential component in both the hydrosphere and atmosphere.

We here provide a first step in developing a taxonomy of physical components of the technosphere. Progress in scientific understanding of the biosphere and of geology began with classification of organisms and of rock strata, early efforts being based on assessments of morphology, size, composition and other easily defined metrics, by Linnaeus, Buffon, Cuvier, William Smith and others. We are now at a comparable early stage in fleshing out the taxonomy of the physical technosphere. Cataloguing and classifying its elements is a subjective and untested process, and omits certain important elements, such as radio waves, that leave no lasting physical entity. Nevertheless, given the current lack of a quantitative inventory of morphological diversity, we provide here a descriptive analysis of form and extent of some technological artefacts and systems. To this are added order-of-magnitude estimates of basic quantities such as mass and spatial dimension.

The physical technosphere is the simplest part of this system to assess in a geological context. Our estimates may help inform both considerations of formal stratigraphy (Waters et al., 2016) and wider discussions on the Anthropocene and its underlying social and technological processes, including those relating to material culture in archaeology (Hodder, 2011). Future work in technospheric taxonomy might include devising classifications of technological morphology and ultimately making connection to dynamical considerations, for instance of energy flows.

\section{Components of the physical technosphere}

We define the physical technosphere as consisting of technological materials within which a human component can be distinguished, with part in active use and part being a material residue. The human signature may be recognized by characteristics including form, function and composition that result from deliberate design, manufacture and processing. This includes extraction, processing and refining raw geological materials into novel forms and combinations of elements, compounds and products.

The active technosphere is made up of buildings, roads, energy supply structures, all tools, machines and consumer goods that are currently in use or useable, together with farmlands and managed forests on land, the trawler scours and other excavations of the seafloor in the oceans, and so on. It is highly diverse in structure, with novel inanimate components including new minerals and materials (Zalasiewicz et al., 2014a), and a living part that includes crop plants and domesticated animals. Humans both produce and are sustained by (and now are dependent on) the rest of the physical technosphere.

Parts of the technosphere, at the end of their useful life, are more or less immediately recycled back into the main active structure: a considerable proportion of aluminium and iron; some glass, paper, plastic; some of the rubble layers beneath cities. Other parts accumulate to form a growing material residue or waste layer (the archaeosphere of Edgeworth et al., 2015) much of which has considerable long-term preservation potential (e.g. Zalasiewicz et al., 2016). This accumulation is most clearly exemplified by modern landfill sites, but also includes gaseous components (e.g. 
Table I. Approximate mass of the major components of the physical technosphere, arranged in order of descending mass (where I $\mathrm{Tt}=10^{12}$ metric tonnes).

\begin{tabular}{lcclcc}
\hline Component & Area $\left(10^{6} \mathrm{~km}^{2}\right)$ & Thickness $(\mathrm{cm})$ & Density $\left(\mathrm{g} / \mathrm{cm}^{3}\right)$ & Mass $(\mathrm{Tt})$ & Percent $(\%)$ \\
\hline Urban areas & 3.70 & 200 & 1.50 & 11.10 & 36.9 \\
Rural housing & 4.20 & 100 & 1.50 & 6.30 & 20.9 \\
Pasture & 33.50 & 10 & 1.50 & 5.03 & 16.7 \\
Cropland & 16.70 & 15 & 1.50 & 3.76 & 12.5 \\
Trawled sea floor & 15.00 & 10 & 1.50 & 2.25 & 7.5 \\
Land use and eroded soil & 5.30 & 10 & 1.50 & 0.80 & 2.7 \\
Rural roads & 0.50 & 50 & 1.50 & 0.38 & 1.3 \\
Plantation forest & 2.70 & 10 & 1.00 & 0.27 & 0.9 \\
Reservoirs & 0.20 & 100 & 1.00 & 0.20 & 0.7 \\
Railways & 0.03 & 50 & 1.50 & 0.02 & 0.1 \\
Totals (where applicable) & 81.83 & & & 30.11 & \\
\hline
\end{tabular}

Notes: Spatial extent is based partially on Hooke et al. (2012), and information on approximate thickness and density are from Ford et al. (2014), Edgeworth et al. (2015) and Gattuso et al. (2009).

carbon dioxide and methane that accumulate in the atmosphere), other more or less disseminated pollutants in the hydrosphere and lithosphere, and soil washed off the land surface as a result of urbanization, agriculture and forestry. The marked growth in the waste layer of the technosphere - reflecting relatively ineffective recycling by comparison with the almost perfect recycling shown by the non-human biosphere - has some uses for humans, locally providing a platform for construction (especially as reclaimed land in coastal areas). It may at times increase biodiversity, as in the construction of artificial reefs, though not always successfully (Sherman and Spieler, 2006). Overall, though, this inefficient recycling is a considerable threat to its own further development and to the parent biosphere (Haff, 2014; Steffen et al., 2004, 2015).

Here we focus on both the active and residual parts of the physical technosphere. Assessing the mass and composition of these is hampered by their complexity, lateral compositional and geometric variability, and rapid change through time. Nevertheless, we provide provisional estimates (Table 1) that, while possessing large uncertainties, nonetheless illustrate the scale of the physical technosphere that now supports Homo sapiens sapiens, allowing our species to populate the planet in numbers far exceeding those attained as hunter-gatherers, by roughly three orders of magnitude (Haff, 2014), and exceeding those of pre-industrial history by about one order of magnitude.

\section{The urban technosphere}

The growing towns and cities (Hooke et al., 2012; Liu et al., 2014) are linked with societal energy flows an order of magnitude greater than those of early agricultural communities (Nakicenovic et al., 2012: 108-115), and disproportionately large attendant impacts on the global environment (Zhu et al., 2012). They are the most obvious part of the technosphere, including buildings, roads, airport runways, docks, quarries, mines and their associated waste dumps, canals, levees, dams, concreted waterways, paved open spaces, with a complexly engineered substructure of foundations, water and energy supply lines, landfills, sewage tunnels, railway lines and metro systems. This assemblage has been partially planned, mapped and archived, but not yet systematically converted into geological terms that would allow full consideration as 'urban strata', to be contrasted with 'natural' geological strata (Figure 1). Archaeologists, though, excavate and record urban layers as distinct from underlying geological strata (Carver, 1987), compiling large data sets relevant to this process. 


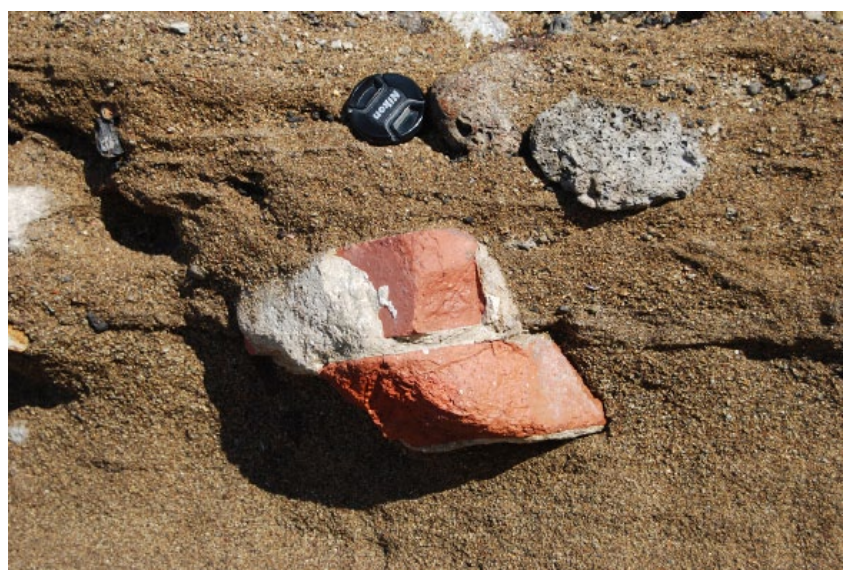

Figure I. Bricks and concrete fragments in carbonate-cemented beach rock deposits on the Tunelboca geosite, Basque region, Spain.

Source: A Cearreta.

Buildings - solid, complex but hollow, air-filled structures - following demolition or destruction can be compacted into a solid layer comprising the brick, concrete, glass, metal, plastic, ceramic, wood and other materials used in architecture. Such demolition is intrinsic to ongoing redevelopment of urban space to maintain its functionality. This demolition can at times be abrupt and widespread, as happened to much of Britain's bomb-damaged housing stock after the Second World War (Saunders, 2005), for instance in Longford Park by Coventry, where part of the valley was filled with 4-6 m of demolition rubble. Equivalent war-derived rubble in Berlin was redistributed in mounds within the city boundary. Fourteen such mounds still exist, the largest being the Teufelsberg hill (Figure 2), comprising Anthropocene rubble up to $80 \mathrm{~m}$ thick, with an area of 1.1 million $\mathrm{m}^{2}$ and an original rubble volume of 26.2 million $\mathrm{m}^{3}$ (Cocroft and Schofield, 2012; Mielke, 2011). Much contemporary armed conflict, too, is characterized by urban warfare, involving extensive destruction of built structures and redistribution of the resulting rubble.

Analysis of the resulting mass of the physical system would require measuring the volume of the buildings and associated structures within any given area using digital surface models (DSMs) of urban areas, together with information of likely internal composition (percentage concrete, brick, glass, wood, etc.) from building and architectural records. Some archaeology-based projects now have similar aims (e.g. de Beer et al., 2012). One needs also include underground substructure, including concrete pilings and services such as sewage, gas and water pipelines and metro systems that may extend tens of metres underground (Zalasiewicz et al., 2014c). In this overview (Table 1), we take a far more generalized approach, outlined below.

The active urban technosphere is largely built on and within its material residue layer, which approximates to what may be delineated on geological maps as varieties of 'artificial ground' - an anthropogenically reworked mixture of rock fragments, soil, building rubble and other forms of waste, locally concentrated as landfill (Ford et al., 2014), and in archaeological records as 'archaeological strata'. Combining these two disciplinary approaches would best categorize and map these material residue layers. The geological mapping, based on information including analysis of borehole records and geophysical surveys, together with archaeological information from excavations and other forms of subsurface investigation, can provide an approximate 3D model of this unit, which may - somewhat counter-intuitively - be easier to construct than that of the functional urban technosphere of the same area. For example, in London, an average thickness of artificial deposits 


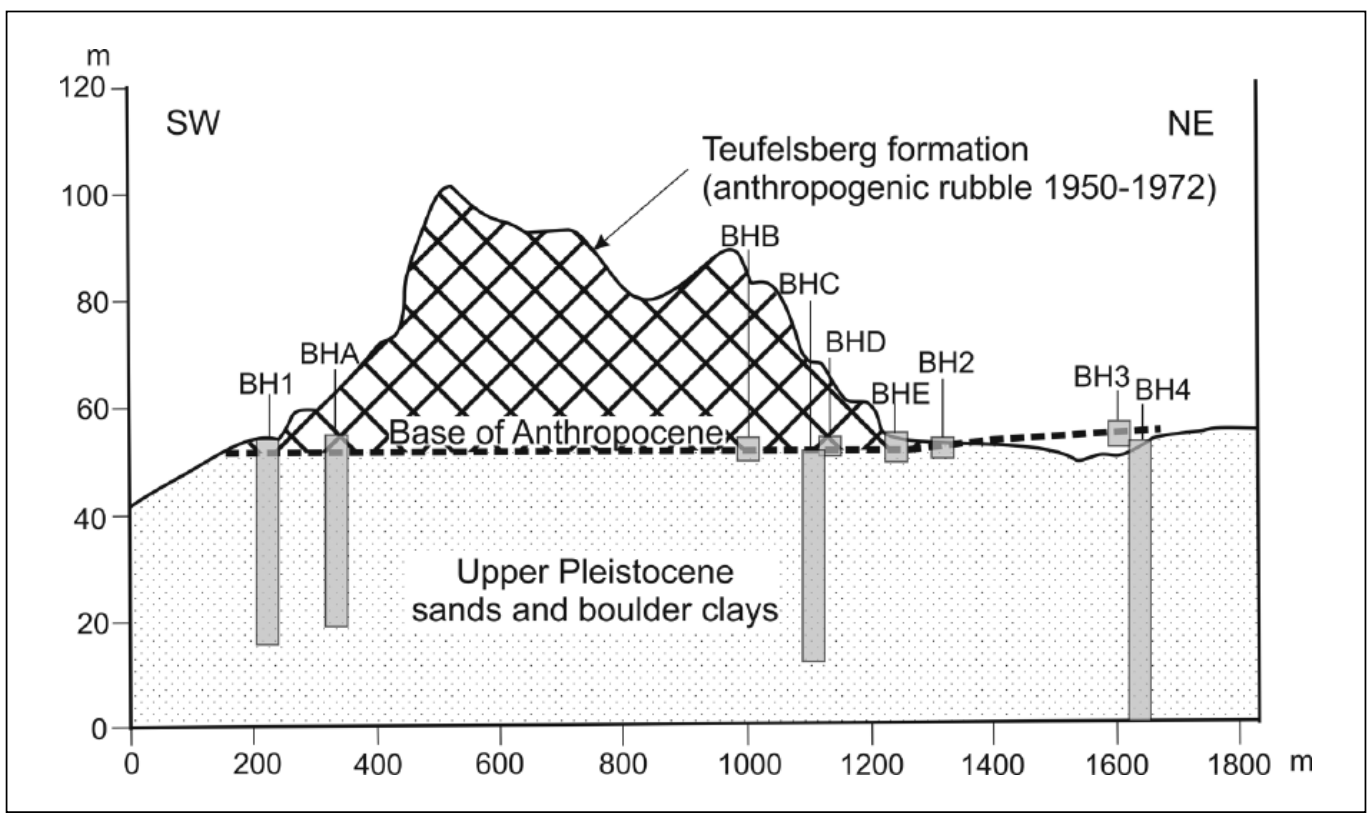

Figure 2. The Teufelsberg Formation (sensu Leinfelder and Scheffold, unpubl.) of war rubble including concrete, brick, clinker, rock, fly ash, slag and solid chemical waste, deposited between 1950 and 1972, forming the highest elevation of Berlin. Thin Holocene deposits may locally separate the Pleistocene and Anthropocene units.

of $1.6 \mathrm{~m}$ has been estimated (Ford et al., 2014), increasing to 8-10 $\mathrm{m}$ in the historic core of the city (Rowsome, 2000), and up to $30 \mathrm{~m}$ deep in places where old docks have been infilled, such as parts of the 2012 Olympics site. Where mineral resource extraction coincides with urban centres (e.g. northern England coalfields), there may also be greater-than-average thicknesses.

Such assessments can provide snapshots in time. In reality, the city is constantly metabolizing (Bettencourt et al., 2007; Kennedy et al., 2011) with inflows of food and water and outflows of sewage produced by its human component, the latter undertaking constant daily migrations with hydrocarbon-powered vehicles (cars, buses, trains, ferries) or ones powered electrically (mostly trains). The urban technosphere is also evolving year on year as building and demolition take place, in effect operating as an anthropogenically driven sedimentary system with inflow, accretion, erosion and outflow of its component materials, here not powered by gravity or by wind, but mainly by directed energy release from hydrocarbons. While the sources of many materials - especially the bulk materials used for building - may be relatively well constrained, the short- and mediumterm sinks of those materials are less so. Ultimately, they or their erosion products will be buried more or less directly, or transported to a sedimentary basin and then buried, depending on the tectonic setting (uplifting or subsiding) of the urban substrate.

\section{The rural technosphere}

Between the urban and rural technosphere is a suburban transitional zone largely comprising lowdensity housing and gardens interlaced with transport networks. Here the 'urban strata' are thinner and patchier than their city correlative, perhaps averaging a metre or so thick. 


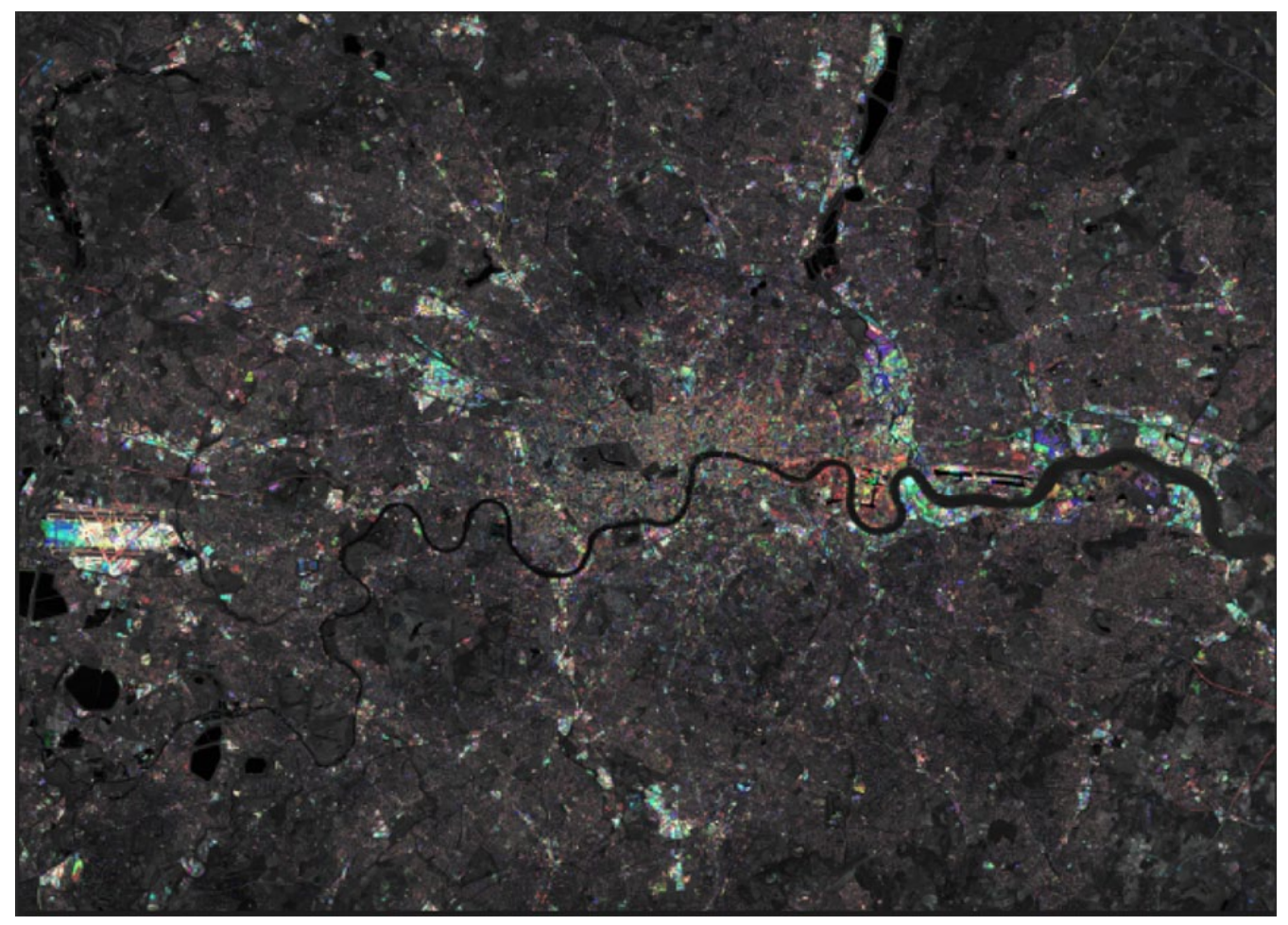

Figure 3. Multiyear analysis of urban/suburban technosphere transformations across London. This multiyear multispectral analysis is derived from Landsat data, and detects transformations in reflectance of hard surfaces. Changes in impervious surfaces (sensed between 0.45 and $0.52 \mu \mathrm{m}$ ) are indicated in different colours (red indicates change to 1989, green 2001 , and blue 2012 ). The image (50 km across) shows the complexity in space and time of transformations over two decades. Additional modifications not detected by this imagery, e.g. underground, will also have occurred.

Source: Territorial Agency /John Palmesino and Ann-Sofi Rönnskog, with David Hellström.

These suburban transition areas have transformed over recent decades into interconnected supply areas and lines along which growing amounts of materials are moved. The pattern of contemporary transformation here is complex and heterogenous through time, often being radially disposed around city centres (Figure 3 ).

Similarly, farther out in rural regions, the areally extensive soil + crop + domestic animal combination, together with the artificial irrigation and drainage networks which allow the croplands to function, may also be placed in the functional technosphere. While this zone might also be regarded as part of a heavily human-modified biosphere, and has also been analysed in terms of anthromes (anthropogenic biomes: Ellis et al., 2010), we categorize it here within the technosphere because of its continual modification into the main resource that sustains the human component of cities. Following this logic, managed forestry (trees + soil) may be placed in this category too, and perhaps also the rivers that traverse it, being largely contained via embankments and locally impounded behind dams (Syvitski and Kettner 2011).

How far may one take this unit? Even the thin soils, rough vegetation and sparse sheep populations of upland pasture (once heavily forested) are essentially all continually modified from preexisting patterns to support human populations. There are relics of a former agricultural landscape 
locally, too, such as the dry-stone walls hidden among the woods of New England, and, scattered across Europe, mounds representing single buildings or whole villages abandoned following the bubonic plagues that once ravaged the region.

In these regions, the residual (waste) component includes scattered landfills and patchy areas of artificial ground, laced with anthropogenic additions that range from nitrate and phosphate compounds, to manure and 'night soil', to pesticide residues. There are earthworks such as embankments, excavations for railways and roads, lynchets (earthen banks) and ridge-and-furrow formations, canals and ditches, and older archaeological features and deposits (Edgeworth, 2014). Sediment washed or blown from ploughed or de-vegetated areas (that may then become 'dustbowls') commonly accumulates on lower slopes, within floodplains or behind dams. Additional localised waste masses relate to the extraction of rocks and minerals (including hydrocarbons and metals) used to construct and power the active urban technosphere, with empty spaces such as quarries often serving also as repository for urban waste. Waste deposition sites may contain complex, often toxic, chemicals, emit methane and other gases, and include collapse-prone voids.

\section{The subterranean technosphere}

The technosphere extends deeply into the subterranean rock mass via mines, boreholes and other underground constructions (Zalasiewicz et al., 2014b). These structures are typically temporary conduits for the managed flux of potable water, liquid and solid effluent, hydrocarbons, metals and minerals (and in the case of subway systems the flux of humans themselves). Even after use they may retain solid form (such as metal borehole casings, concrete grouting and pit props). Some may retain longer-term use (as with underground salt caverns for gas storage), while others may be actively converted into the waste technosphere, like the sophisticated, highly engineered structures for nuclear waste storage. There is also disturbance of the rock mass itself, e.g. through collapse of underground cavities or hydraulic fracturing, propagating fractures and chemically modifying the rock mass far beyond the immediate intrusion site. The subterranean technosphere is difficult to quantify and is not included in the estimate of technosphere mass shown in Table 1.

\section{The marine technosphere}

The technosphere reaches far into the marine realm; the most obvious representatives comprise mobile technological objects (ships, submarines) and more or less fixed ones (oil platforms and pipelines, piers, docks, aquaculture structures). The latter include construction at the sea's margin for transport (ports and harbours) and to stabilize coastlines or reclaim seabed areas (sea walls, polders and artificial islands).

There are other, larger components. The bottom-trawled area of sea floor now extends over most of the continental shelves, and locally out onto the continental slope; this is the submarine equivalent of terrestrial agricultural soils, repeatedly ploughed to depths of some decimetres to scrape up seafood to feed humans, locally triggering sediment gravity flows (Martin et al., 2015). Volumes of seawater, too, are systematically fished, now dramatically altering global fish stocks (Pauly et al., 1998); not easily defined, and not quantified here, these spaces have nevertheless effectively been co-opted into the technosphere.

The waste component of the submarine technosphere includes a land-derived component, most vividly demonstrated by dumped masses of garbage, spoil masses from coastal mining operations, war debris including wrecks and dumped munitions, ballast material from ships (WBGU, 2013), and widely dispersed plastic debris (Ivar do Sul and Costa, 2014; Zalasiewicz et al., 2016). Less obvious, but potentially definable, are deposits remobilized and transported by bottom trawling (Martin et al., 
2015) and other anthropogenic sea floor disturbances. These processes may effect significant biosphere change, as in reef systems in the Caribbean, where organic waste accumulation has reduced some reefs to a microbial mat state (Brocke et al., 2015). Components here also include oil from spills, plastics, dissolved CFCs and bomb-produced radiocarbon $\left({ }^{14} \mathrm{C}\right)$.

\section{The aerial technosphere}

The atmosphere is a space now continually crossed by aircraft, mostly along specific migratory paths. In this and in other ways (such as providing oxygen for both biological and industrial respiration, wind for turbines, and passage for radio waves) it may be regarded as an enabling medium for the technosphere, rather than a component of it per se. A specific component is internal air in buildings, modified and controlled for temperature and humidity, across a global stock of buildings now covering $>150$ billion $\mathrm{m}^{2}$ (Nakicenovic, et al., 2012).

The atmospheric waste component of the technosphere includes carbon dioxide, methane, chlorofluorocarbons, nitrous oxide and other greenhouse gases added by industrial and agricultural activities, with effective lifetimes from years to many millennia. Without massive, directed anthropogenic intervention, it will take many millennia for the elevated $\mathrm{CO}_{2}$ levels to decline to nearbackground levels (Tyrrell, 2011). A particulate component comprises aerosols, radiogenic fallout (Waters et al., 2015) and fly ash (Oldfield, 2015; Rose, 2015), though these are typically shortlived, being rained out onto the ground and into the hydrosphere.

Each year, a quantity of carbon dioxide in excess of 2 parts per million (ppm) now accumulates in the atmosphere (Rubino et al., 2013; Waters et al., 2016), equivalent to about 17 billion tonnes (Gt) of carbon dioxide annually. The total anthropogenic carbon dioxide burden in the atmosphere $(120 \mathrm{ppm}$ as of 2015 , nearly one-third of the total) weighs in at nearly one 1 trillion tonnes $(\mathrm{Tt}=$ $10^{9}$ ) - the mass equivalent of about 150,000 of Khufu's Great Pyramid of Egypt - or, as gas at atmospheric pressure, the equivalent of a pure $\mathrm{CO}_{2}$ gas layer $\sim 1 \mathrm{~m}$ thick around the whole globe (and now thickening at the rate of $\sim 1 \mathrm{~mm}$ every two weeks). This does not represent all anthropogenic $\mathrm{CO}_{2}$ emissions - approximately one-quarter has been dissolved into the oceans or assimilated by ocean phytoplankton, while the other quarter has been taken up by land biota. The growth of these gases in the atmosphere is measurable in bubbles of fossil air in ice cores, while dissolving excess $\mathrm{CO}_{2}$ in the ocean engenders acidification and declining carbonate accretion in organisms such as corals (Albright et al., 2016) and pteropods (Bednaršek et al., 2012).

The technosphere, since 1957, has extended beyond the atmosphere into outer space in the form of satellites and related debris orbiting the Earth, and spacecraft elsewhere in, and occasionally heading beyond, the Solar System (Gorman, 2014).

\section{The physical technosphere and the geological Anthropocene}

The material technosphere differs considerably from the stratigraphic record of the Anthropocene (i.e. the Anthropocene Series, the material equivalent of the Anthropocene Epoch: Zalasiewicz et al., 2011, 2014c). The Anthropocene Series comprises all strata laid down during the Anthropocene, whenever that is eventually deemed to have begun (Waters et al., 2016). It includes anthropogenic deposits (e.g. recent urban strata) and non-anthropogenic ones (desert sands, say, that have accumulated without perceptible human influence during Anthropocene time).

The anthropogenic component of the Anthropocene Series, if standard geological terminology applies, approximates to various types of artificial ground among the technosphere waste, including bodies of building rubble and landfill, and active technosphere (e.g. embankments). Many types of artificial deposit remain active, such as landfills and foundations undergoing modification. 
Modern soils (whether agricultural or not) might be reasonably considered part of the Anthropocene Series, though these are not typically included on geological maps. If soil is worked (as opposed to undisturbed and natural) then it would also form part of the related concept of the archaeosphere (Edgeworth, 2014). The Anthropocene Series would not, in traditional classification, include the most obvious parts of the active technosphere, such as buildings and motor vehicles (these are generally only considered stratal components once reduced to rubble layers or landfill deposits). It would, though, include layers of deep-sea sediment and snow and ice on icecaps, which do not form part of either active or waste-layer technosphere, though they typically contain tiny amounts of waste material (far-travelled soot, artificial radionuclides, excess carbon dioxide in trapped air and chemical pollutants such as lead, sulphate and polychlorinated biphenyls).

Hence, the physical technosphere provides an alternative prism within which the Anthropocene phenomenon can be considered, that more clearly reflects its dynamic nature than does the chronostratigraphic Anthropocene Series. One of the most remarkable aspects of the technosphere is the diversity and rapid evolution of its technological components; these, the technofossils of the present and future (Zalasiewicz et al., 2014d), are already attaining a level of diversity and abundance exceeding recognized fossil diversity.

\section{Technospheric diversity and richness}

How can one measure the diversity of technofossils? One might, perhaps, do this in the same way as palaeontologists measure the diversity of fossil organisms. This cannot be done quite as modern biodiversity is defined and measured, where a common approach tallies the number of biological species (or alternatively genera, or families, or lineages) living at any one time, this number being termed taxonomic richness. One commonly used definition of species (in eukaryotic organisms i.e. those with a membrane-bound nucleus) is based on ability to interbreed and produce viable offspring under natural conditions, this definition being typically allied to (but not perfectly mirrored by) morphological distinctness. The number of eukaryotic organisms so described as species is $<2$ million, though estimates of the total number, including undescribed species, has ranged from $\sim 3$ to $\sim 100$ million, with recent estimates at between 5 and 15 million (Mora et al., 2011, for instance, suggest $\sim 9$ million eukaryotic species). Bacterial diversity, estimated in the thousands by classical techniques, is now known to number some millions of distinct types of organisms using DNA-sequencing information, though metazoan species concepts are hard to apply.

The total number of species that has existed in the past is much greater than the number of currently existing species. Assuming an average species-span is $\sim 2-5$ million years, then the halfbillion years of the Phanerozoic Eon has seen the passage of about 1 billion metazoan species. Of those, only something like 300,000 have been described and named - less than one in a thousand. Why? Many were soft-bodied, and so unlikely to fossilize, and others were simply rare. Upland terrestrial zones are likely to have been eroded, leaving no trace of the animals or plants that once lived there, while the record of the deep ocean floor is eventually obliterated by subduction.

Fossil species, too, are morphospecies, based upon morphological distinctiveness alone, as it is impossible to say which organisms interbred. Where preserved morphology is simple (as in the spherical sphaeromorph acritarchs, the fossilized cysts of ancient planktonic algae) then original genetic diversity is very poorly reflected by the limited morphospecies diversity recognized.

Of the recognized fossil species, perhaps a few thousand are of trace fossils, of tracks, trails, burrows, nests and footprints. Like body fossils, these are also classified morphologically and placed within Linnean nomenclature as morphospecies. Although only rarely linked with the tracemaking organism at species level, trace fossils provide key behavioural information typically absent from morphological fossils. 
One might treat artefact types as distinct morphological entities, i.e. as trace fossil (or technofossil) morphospecies. Detailed comparison of biodiversity with total technofossil diversity is currently impossible. The incompleteness of our cataloguing of both modern and fossil species (including trace fossil species) is a factor, but is dwarfed by our ignorance of the number of artefact types that have been made. Unlike the case with taxonomic species databases, there are no inventories of the total diversity of artefacts that we are aware of, and few of any class of artefact or tool, particularly those made in modern times.

Nevertheless, comparisons with the diversity of specific types of technofossil are revealing. One commonly produced potential technofossil is the book, and a recent Google-based assessment of titles revealed $\sim 130$ million individual titles (http://mashable.com/2010/08/05/number-ofbooks-in-the-world/\#443wpuoowEqT), recorded since publishing began, with now over a million new titles each year in the USA alone. These titles range from bestsellers produced in millions, to doctoral theses of which only a few copies exist; each title nevertheless can be regarded as a distinct, biologically-produced morphological entity with its own specific pattern of printed words, pages, dimensions and texture.

A more recent, 'fossilizeable' example comprises mobile phones, commercially available since 1983 , and with $\sim 6.8$ billion unique mobile phone connections made by 2014 , operating via hundreds of 'technospecies' with complexity of both external and internal structure, of good fossilization potential (Zalasiewicz et al., 2014d, 2016).

The total number of artefacts with technofossil potential is unknown, but might exceed by an order of magnitude the number of book titles. If so, and if such comparison is valid, this number would equal or exceed the total global biodiversity that has existed on Earth. The technosphere, thus, represents an unparalleled increase in biologically fashioned morphological diversity at the Earth's surface, which is developing a complexity (in computer-based products, for instance) that might someday rival biological complexity.

As with biological species, not all technofossils will be recognizable following the information loss associated with fossilization. Future fossilized books, for instance, will likely be rectangular carbonized masses classifiable by size and relative dimensions and subtle variations in surface texture; fragmentary details of the print information will only be rarely preserved, as are fragmentary details of DNA structure in some exceptionally preserved ancient fossils today. Hence - as with the sphaeromorph acritarchs - the true diversity will be hidden among the smaller number of morphospecies identifiable in practice. The record of more robust and complex technofossils will better reflect original diversity.

\section{Conclusions}

The physical technosphere - that part which can be most easily considered in relation to stratigraphy - is characterized by both active and residual components. Continuous growth, transformation and re-incorporation takes place among these components, and its scope is now global.

Highly preliminary estimates of the major components of the Earth System co-opted into the technosphere (Table 1) indicate a mass of $\sim 30$ trillion tonnes (Tt), equivalent to $>50 \mathrm{~kg} / \mathrm{m}^{2}$ of the Earth's surface. The total is five orders of magnitude greater than the standing biomass of humans ( $\sim 0.3 \mathrm{Gt}$; Smil, 2011) presently sustained by this construct and its reshaping of the biosphere. The enormous scale of the technosphere by comparison to pre-anthropogenic systems becomes even more apparent when one considers that present human biomass is more than double that of all large terrestrial vertebrates that characterized the Earth prior to human civilization (Barnosky, 2008) and is an order of magnitude greater than present wild terrestrial vertebrate biomass (Smil, 2011).

It is difficult to assess the accuracy of the numbers offered in Table 1. However, they appear to be of the correct order of magnitude. For example, if one calculates the mean thickness of the 
terrestrially expressed physical technosphere needed to produce $27.73 \mathrm{Tt}$ (total minus sea trawling; Table 1), assuming roughly half the landmass (i.e. 69.6 million $\mathrm{km}^{2}$; Hooke et al., 2012) is modified by humans, one obtains a value of $26.6 \mathrm{~cm}(24.2-29.4 \mathrm{~cm}$ at $1 \sigma)$, which lies within the range of thickness estimate provided $(10--200 \mathrm{~cm})$.

Further assessment of the evolving mass and compositional characteristics of the physical technosphere will allow it to be more precisely compared with allied phenomena such as the biosphere from which it originated, the stratigraphic Anthropocene in which it is preserved, and the archaeosphere which details the cultural contexts of its formation. While the long-term development of the technosphere remains uncertain (Williams et al., 2015), its scale and accelerating diversification of form means that it already represents a distinctive new component at a planetary scale.

\section{Acknowledgements}

We thank Roger LeB. Hooke, Robert M. Hazen for their perceptive and constructive reviews and Deodato Tapete and the editorial board of this special issue, for thoughtful and useful suggestions and comments as this paper was evolving. Colin Waters and Simon Price publish with the permission of the Director of the British Geological Survey.

\section{Funding}

This research received no specific grant from any funding agency in the public, commercial, or not-for-profit sectors.

\section{References}

Albright R, Caldeira L, Hosfelt J et al. (2016) Reversal of ocean acidification enhances net coral reef calcification. Nature 531: 362-365.

Barnosky AD (2008) Megafauna biomass tradeoff as a driver of Quaternary and future extinctions. Proceedings of the National Academy of Sciences of the USA 105: 11,543-11,548.

Basalla G (1988) The Evolution of Technology. Cambridge University Press, Cambridge, UK.

Bednaršek N, Tarling GA, Bakker DCE et al. (2012) Extensive dissolution of live pteropods in the Southern Ocean. Nature Geoscience 5: 881-885.

Bettencourt LMA, Lobo J, Helbing D et al. (2007) Growth, innovation, scaling, and the pace of life in cities. Proceedings of the National Academy of the USA 104: 7301-7306.

Brocke HJ, Polerecky L, de Beer D et al. (2015) Organic matter degradation drives benthic cyanobacterial mat abundance on Caribbean coral reefs. PLOS ONE 10(5): e0125445. doi:10.1371/journal.pone.0125445.

Carver M (1987) Underneath English Towns. Interpreting Urban Archaeology. London: Batsford.

Cocroft W and Schofield G (2012) The secret hill: Cold War archaeology of the Teufelsberg. British Archaeology 126: 38-43.

de Beer J, Price SJ and Ford JR (2012) 3D modeling of geological and anthropogenic deposits at the World Heritage Site of Bryggen in Bergen, Norway. Quaternary International 251: 107-116.

Edgeworth M (2014) The relationship between archaeological stratigraphy and artificial ground and its significance In: Waters CN, Zalasiewicz J, Williams M et al. (eds) A stratigraphical basis for the Anthropocene. Geological Society of London Special Publication 395: 91-108.

Edgeworth M, Richter DDeB, Waters CN et al. (2015) Diachronous beginnings of the Anthropocene: The lower bounding surface of anthropogenic deposits. Anthropocene Review 2(1): 1-26.

Ellis EC (2015) Ecology in an anthropogenic biosphere. Ecological Monographs 85(3): 287-331.

Ellis EC, Klein Goldewijk K, Sinert S et al. (2010) Anthropogenic transformation of the biomes, 1700 to 2000. Global Ecology and Biogeography 19: 589-606.

Ford JR, Price SJ, Cooper AH et al. (2014) An assessment of lithostratigraphy for anthropogenic deposits. In: Waters CN, Zalasiewicz J, Williams $\mathrm{M}$ et al. (eds) A stratigraphical basis for the Anthropocene. Geological Society of London Special Publication 395: 55-89. 
Gattuso JP, Smith SV, Hogan CM et al. (2009) Coastal zone. In: Cleveland CJ (ed.) Encyclopedia of Earth. Environmental Information Coalition. National Council for Science and the Environment, Washington, DC. (First published in the Encyclopedia of Earth, see http://www.eoearth.org/article/Coastal_zone).

Gorman A (2014) The Anthropocene in the solar system. Journal of Contemporary Archaeology 1(1): 87-91. Haff P (2014) Technology as a geological phenomenon: Implications for human well-being. In: Waters CN, Zalasiewicz J, Williams M et al. (eds) A stratigraphical basis for the Anthropocene. Geological Society, London, Special Publications 395: 301-309.

Hall CAS (1975) The biosphere, the industriosphere and the interactions. Bulletin of the Atomic Scientists 31(3): 11-21.

Hodder I (2011) Human-thing entanglement: Towards an integrated archaeological perspective. Journal of the Royal Anthropological Institute 17: 154-177.

Hooke RLeB, Martín-Ducque JF and Pedraza J (2012) Land transformation by humans: A review. GSA Today 22(12): 4-10.

Ivar do Sul JA and Costa MF (2014) The present and future of microplastic pollution in the marine environment. Environmental Pollution 185: 352-364.

Kennedy C, Pincetl S and Bunje P (2011) The study of urban metabolism and its applications to urban planning and design. Environmental Pollution 159: 1965-1973.

Koops K, Furuichi T and Hashimoto C (2015) Chimpanzees and bonobos differ in intrinsic motivation for tool use. Science Reports 5: 11356; doi: 10.1038/srep11356.

Krützen M et al. (2005) Cultural transmission of tool use in bottlenose dolphins. Proceedings of the National Academy of the USA 102: 8939-8943.

Liu Z, He C and Zhou Y (2014) How much of the world's land has been urbanized, really? A hierarchical framework for avoiding confusion. Landscape Ecology 29: 763-771.

Martin J et al. (2015) Commercial bottom trawling as a driver of sediment dynamics and deep seascape evolution in the Anthropocene. Anthropocene 7: 1-15.

Mesoudi A, Whiten A and Laland KN (2006) Towards a unified science of cultural evolution. Behavioral and Brain Sciences 29: 329-347.

Mielke H-J (2011) Wald und Politik: Die unendliche Geschichte des Berliner Teufelsberges. Berlin: ProjekteVerlag Cornelius GmbH, 48 pp.

Milsum JH (1968) The technosphere, the biosphere, the sociosphere. IEEE Spectrum 5(6): 76-82.

Mora C, Tittensor DP, Adl S et al. (2011) How many species are there on Earth and in the ocean? PLoS Biology 9: e1001127. doi:10.1371/journal.pbio.1001127.

Nakicenovic N et al. (2012) Global Energy Assessment (GEA), Toward a Sustainable Future. GEA-IIAASA, Cambridge, UK: Cambridge University Press.

Oldfield F (2015) Can the magnetic signatures from inorganic fly ash be used to mark the onset of the Anthropocene? Anthropocene Review 2(1): 3-13.

Pauly D, Christensen V, Dalsgaard J et al. (1998) Fishing down marine food webs. Science 279: 860-863.

Roelofs YC (2010) Tool use in birds: An overview of reported cases, ontogeny and underlying cognitive abilities. M. Sc. thesis, University of Groningen, Netherlands.

Rose NL (2015) Spheroidal carbonaceous fly ash particles provide a globally synchronous stratigraphic marker for the Anthropocene. Environmental Science and Technology 49(7): 4155-4162.

Rowsome P (2000) Heart of the City: Roman, Medieval and Modern London Revealed by Archaeology at 1 Poultry. Museum of London Archaeology Service and English Heritage, London, UK.

Rubino $\mathrm{M}$ et al. (2013) A revised 1000 year atmospheric $\mathrm{d}^{13} \mathrm{C}-\mathrm{CO}_{2}$ record from Law Dome and South Pole, Antarctica. Journal of Geophysical Research 118: 8482-8499.

Saunders A (2005) London County Council Bomb Damage Maps 1939-45. London Topographical Society, London, UK.

Sherman RL and Spieler RE (2006) Tires: Unstable materials for artificial reef construction. Transactions on Ecology and the Environment 88: 215-223.

Smil V (2011) Harvesting the biosphere: The human impact. Population and Development Review 37: 613-636.

Steffen W, Sanderson A, Tyson PD et al. (2004) Global Change and the Earth System: A Planet Under Pressure. The IGBP Global Change Series. Berlin; Heidelberg; New York: Springer-Verlag, 336 pp. 
Steffen W et al. (2015) The trajectory of the Anthropocene: The Great Acceleration. The Anthropocene Review 2(1): 81-98.

Syvitski JPM and Kettner A (2011) Sediment flux and the Anthropocene. Philosophical Transactions of the Royal Society of London A 369: 957-975.

Tyrrell T (2011) Anthropogenic modification of the oceans. Philosophical Transactions of the Royal Society of London A 369: 887-908.

Vernadsky VI (1929) La Biosphère. Paris: Librairie Félix Alcan.

Waters CN, Syvitski JPM, Gałuszka A et al. (2015) Can nuclear weapons fallout mark the beginning of the Anthropocene Epoch? Bulletin of the Atomic Scientists 71(3): 46-57.

Waters CN, Zalasiewicz J, Summerhayes C et al. (2016) The Anthropocene is functionally and stratigraphically distinct from the Holocene. Science 351: 137.

WBGU (2013) World in Transition. Governing the Marine Heritage. Flagship Report, German Advisory Council on Global Change, WBGU Berlin, 362 pp.

Williams M et al. (2015) The Anthropocene biosphere. The Anthropocene Review 2: 196-219.

Wright JP, Jones CG and Flecker AS (2002) An ecosystem engineer, the beaver, increases species richness at the landscape scale. Oecologia 132: 96-101.

Zalasiewicz J et al. (2011) Stratigraphy of the Anthropocene. Philosophical Transactions of the Royal Society of London A 369: 1036-1055.

Zalasiewicz J, Kryza R and Williams M (2014a) The mineral signature of the Anthropocene. In: Waters CN, Zalasiewicz J, Williams M et al. (eds) A stratigraphical basis for the Anthropocene. Geological Society, London, Special Publications 395: 109-117.

Zalasiewicz J, Waters CN and Williams M (2014b) Human bioturbation, and the subterranean landscape of the Anthropocene. Anthropocene 6: 3-9.

Zalasiewicz J et al. (2014c) Can an Anthropocene Series be defined and recognized? In: Waters CN, Zalasiewicz J, Williams M and et al. (eds) A stratigraphical basis for the Anthropocene. Geological Society of London, Special Publications 395: 39-53.

Zalasiewicz J, Williams M, Waters CN et al. (2014d) The technofossil record of humans. Anthropocene Review 1: 34-43.

Zalasiewicz J et al. (2016) The geological cycle of plastics and their use as a stratigraphic indicator of the Anthropocene. Anthropocene 13: 4-17.

Zhu T, Melamed M, Parrish D et al. (2012) Impact of Megacities on Air Pollution and Climate. WMO World Meteorological Organization, Geneva, Switzerland. 